\title{
MAPPING LAND COVER DAMAGES IN MEGA FLOODS THROUGH INTEGRATION OF REMOTE SENSING AND GIS TECHNIQUES
}

Sikandar Ali

Indus University. Karachi (Pakistan) E-mail: sikandar.shah@indus.edu.pk

Gasim Alandjani Yanbu University College. Yanbu (Saudi Arabia)

E-mail: alandjanig@rcyci.edu.sa

\section{Gitación sugerida:}

Ali, S. y Alandjani, G. (2019). Mapping Land Cover Damages in Mega Floods through Integration of Remote Sensing and GIS Techniques. 3C Tecnología. Glosas de innovación aplicadas a la pyme. Edición Especial, Mayo 2019, pp. 258-275. doi: http://dx.doi. org/10.17993/3ctecno.2019.specialissue2.258-275

\section{Suggested citation:}

Ali, S. \& Alandjani, G. (2019). Mapping Land Cover Damages in Mega Floods through Integration of Remote Sensing and GIS Techniques. 3C Tecnología. Glosas de innovación aplicadas a la pyme. Special Issue, May 2019, pp. 258-275. doi: http://dx.doi. org/10.17993/3ctecno.2019.specialissue2.258-275 


\section{ABSTRACT}

Today we are encircled by multiple problems, such as global warming, drought, wildfires, Hurricanes and tropical storms etc; among them, flooding is one of the major problems; however, the flood hazards are probably rising due to an amalgamation of environmental and socio-economic effects. Therefore flood safety measurements are more essential to avoid barriers toward major development in society associated with the environment, which requires modern and accurate steps for preventing the impacts of the flood on population and properties. Floods are among the most destructive physical vulnerabilities on the earth's surface, which cause major economic and social damages rather than any other natural incidence. However, the flood problem begins because human beings are using river floodplains.

In this research our focus is to identify and measure extent and impacts such as Infrastructural, loss of Agriculture, Built-up (Houses), natural vegetation and property along Indus river due to heavy flooding of 2010, to achieve our purpose, two different years Landsat imageries before and after flood i.e September 2009 and September 2010 have been applied and the desired results were achieved through the integration of Remote Sensing (RS) and Geographical Information System (GIS) techniques.

With the help of RS data, hazardous impacts of flooding 2010 have been observed on the bases of different factors which were performed on Arc Map 10.3.1, Erdas Imagine 9.2, eCognition Developer 64. After performing different analysis the major losses have been observed which are shown in table 1to4 and further highlighted in Figure 5a to 8g.

\section{KEYWORDS}

Land-sat 5 Thematic Mapper (TM), Flood Hazards, OBE classification, Error Matrix, Accuracy assessment. 


\section{INTRODUCTION}

According to the worldwide climatic researcher, they believe that all climatic changing is caused by human activities, and it will increase unless any mitigation actions are successfully applied (Anderegg, Prall, Harold \& Schneider, 2010; Sellers, 1969). The flood hazards are probably to rise due to an amalgamation of environmental and socio-economic effects. It directs to various floodplains are debarred from sustainable development. Therefore its safety is more essential towards the development of society, which requires modern and accurate measures to prevent the impacts of the flood on people and properties.

The flood which may cause property at high risk including housing, transportation and public service, infrastructure, commercial, industrial and agricultural areas. It is a familiar natural disaster which added approximately $40 \%$ of a worldwide natural hazard(Fedorov, Badenko, Maslikov \& Chusov, 2016)(Hapuarachchi, Wang \& Pagano, 2011). Floods are among the most destructive physical vulnerabilities on the earth's surface, which cause major economic and social damages rather than any other natural incidence. While through assessment and analysis it has been observed that flood hazard is a serious problem of human beings, because mostly they are using river floodplains that create huge physically and mentally disturbance (Irimescu, Stancalie, Craciunescu, Flueraru \& Anderson, 2009). During flood time mapping of the flood area is more essential for emergency planning but it needs fast acquirement, processing and data analysis to accomplish the requirement. However accessibility in a few hours sustains emergency relief planning and assists to coordination of the response activities of different decision makers so they require two kinds of rapid mapping products, an overview maps of flooded areas and damage maps united with extra information, such as flood extent distinction or land-use types within the flooded area (Trianni \& Gamba, 2008). The remote sensing is a significant field which gives rapid information of an area, thus it has more useful and extensive applications in the field of disaster management. Generally, space-based platforms give extensive spatial coverage without access restrictions while ground-based observing networks are unable to provide sufficient information because of the low density of monitoring points. 
Although in this scenario flood risk zones can be mapped and monitor through Satellite observation (Irimescu, Craciunescu, Stancalie \& Nertan, 2010). With the help of remote sensing data, we can map flooded risky areas, land cover, drainage networks, specific river basin modelling, and a post-event estimation of damaged areas (Trianni \& Gamba, 2008).

The flood hazard measurement needs integrative approaches and studies, the possible flood hazard may be decreased by reducing the intensity of vulnerability, decreasing the exposure value and decreasing the risk (Dang, Babel \& Luong, 2011). It is world widely accepted that flood is the major indicator of hazardous damages and associated damages are categorized as direct or indirect. The environmental and agricultural damages are the results of the directly associated flood while indirect damages effect on the regional or national economy such as business interruption. Also, indirect damages have health and psychological losses ("A mathematical model for flood loss estimation," 2003). It has been observed that during the monsoon period between July and September river flood generally occurs as a consequence of serious rainfall in the stream drainage area, which causes the flood usually in dry areas due to high water volume in the river.

Pakistan is a flood-prone country with a history of extensive and continual flooding, almost average floods in Pakistan are observed in monsoon periods and the most hazardous flood was occurred on mid July 2010 which caused by serious monsoon rainfall in most regions of the country, about $1 / 5^{\text {th }}$ total land area was affected mostly Punjab, KPK, Baluchistan and Sindh.

According to Metrological Department of Pakistan the regular rainfall in the months of July and August 2010 was evaluated (Forecast 2010), and the flood wave progression monitored (Monsoon 2010), the discharge levels were compared with the floods of 1988, 1995, and 1997 (Past floods 2010), as a result overall the monsoon rainfall of 2010 was the highest since 1994 throughout the preceding 50 years. Since 1947-2014, floods in Pakistan especially in the Indus River Basin have been caused loss of lives, million acres and enormous infrastructure and crop losses (Haq, Memon, Muhammad, 
Sidiqui, \& Rahmatullah, 2012). The destruction during the flooding 2010 that harm to the economy of the country which is estimated more than US $\$ 4$ billion (Flood Events, 2010). the flood was destroyed different areas from upper Punjab and moved southward along the Indus basin toward the southern areas of Sindh province (BBC 2010), and the most seriously damaged areas were as Kashmore, Ghotki, Sukkur, Shikarpur, Jacobabad, (PDMA. Sindh, 2011).

\section{STUDY AREA}

The whole province was damaged by the flood of 2010 but most vulnerable districts such as Kashmore, Ghotki, Sukkur, and Shikarpur with 10 flooded talukas were selected for the studies along Indus River which are shown in Figure 1. These districts are located on both sides of Indus River on the North West and North East portion of Sindh province, Pakistan. Geographically Study area extends from $28^{\circ} 25^{\prime} 39.69^{\prime} \mathrm{N}, 69^{\circ} 42^{\prime} 47.34^{\prime \prime} \mathrm{E}$ to $27^{\circ} 42^{\prime} 3.38^{\prime \prime} \mathrm{N} 68^{\circ} 28^{\prime} 34.42^{\prime \prime} \mathrm{E}$ with a mean elevation of $55 \pm 4 \mathrm{~m}$. covering an area of $2619.91 \mathrm{~km}^{2}$.

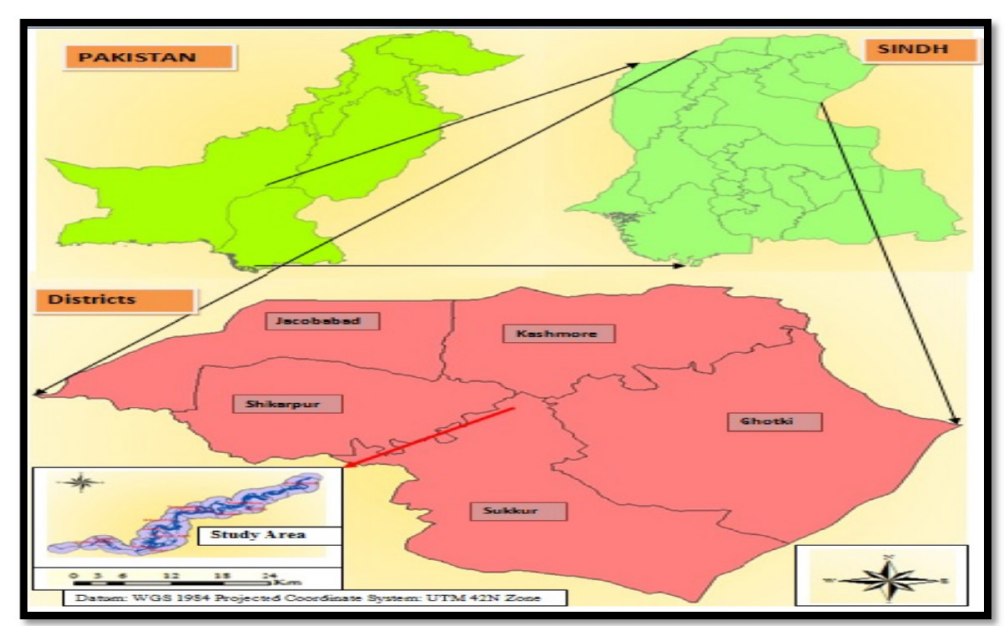

Figure 1. Location of Study area.

The study area has a monsoon climatic region at an average maximum and minimum temperatures are $42^{\circ} \mathrm{C}$ and $31^{\circ} \mathrm{C}$, respectively, June is the hottest month of the year. While in the month of January the lowest average temperatures reach 
approximately $14.8{ }^{\circ} \mathrm{C}$. During the year precipitation in the region is about 130 $\mathrm{mm}$, the lowest in the month of October, with an average of $2 \mathrm{~mm}$, which is not sufficient for crop water requirements. However, mostly region is agricultural region. These areas are most cultivated and common rotation crops are as rice, cotton, maize, mash, fodder, sugarcane and wheat while these crops are divided into two types such as summer (Kharif) and winter (Rabi). The rice and cotton crops sown in the month of June to September on most of the agricultural lands while it's harvesting starts in the middle of October and continues to the end of November, whereas wheat sown in Rabi season which starts November to March and approximately $30 \%$ of the area covered by Rabi types of crops . it has been observed that before flooding 2010 most area was cultivated by Kharif type of crops i.e rice and cotton which were hazardously damaged by flooding 2010 which was begun in late July 2010.

\section{METHODOLOGY}

The Figures 2 and 3 show the process of flood hazard, where data have been collected, processed and analyzed the major flood damages then finalized through efficiently techniques of remote sensing (RS) and Geographical Information system (GIS).

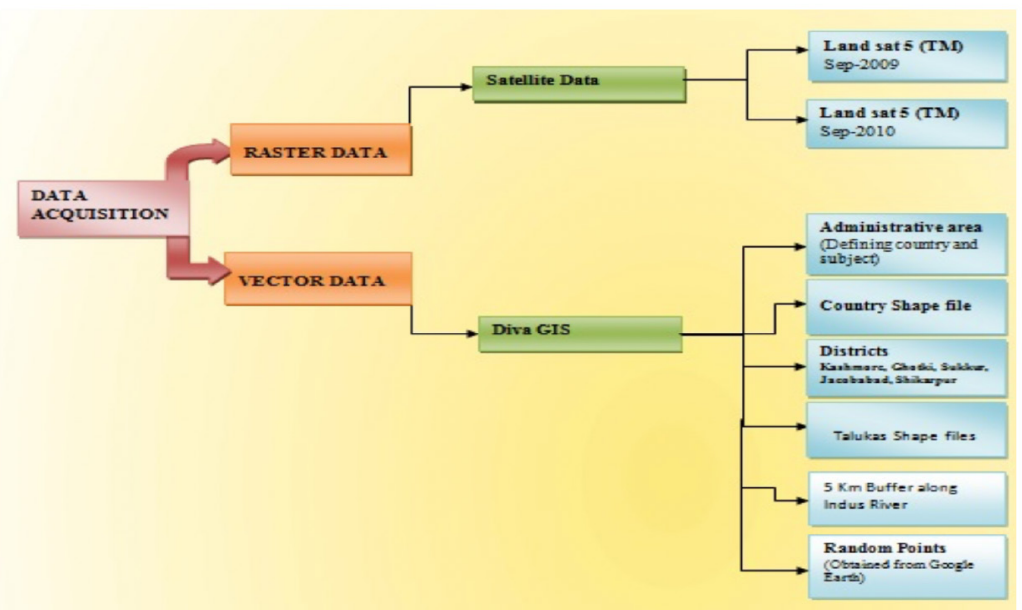

Figure 2. Flow chart shows data Acquisition. 
In data pre-processing the geometric and radiometric correction were carried out and then imageries stacked by selected required bands, after stacking layer the images were mosaic by using ERDAS Imagine 9.2 software, while using clip tool on ArcMap10.3.1software, the study area/Area Of Interest (AOI) with 5km buffer on both sides of Indus river was developed and classified to recognize different types of land--use and land--cover (LULG) before and after flood.

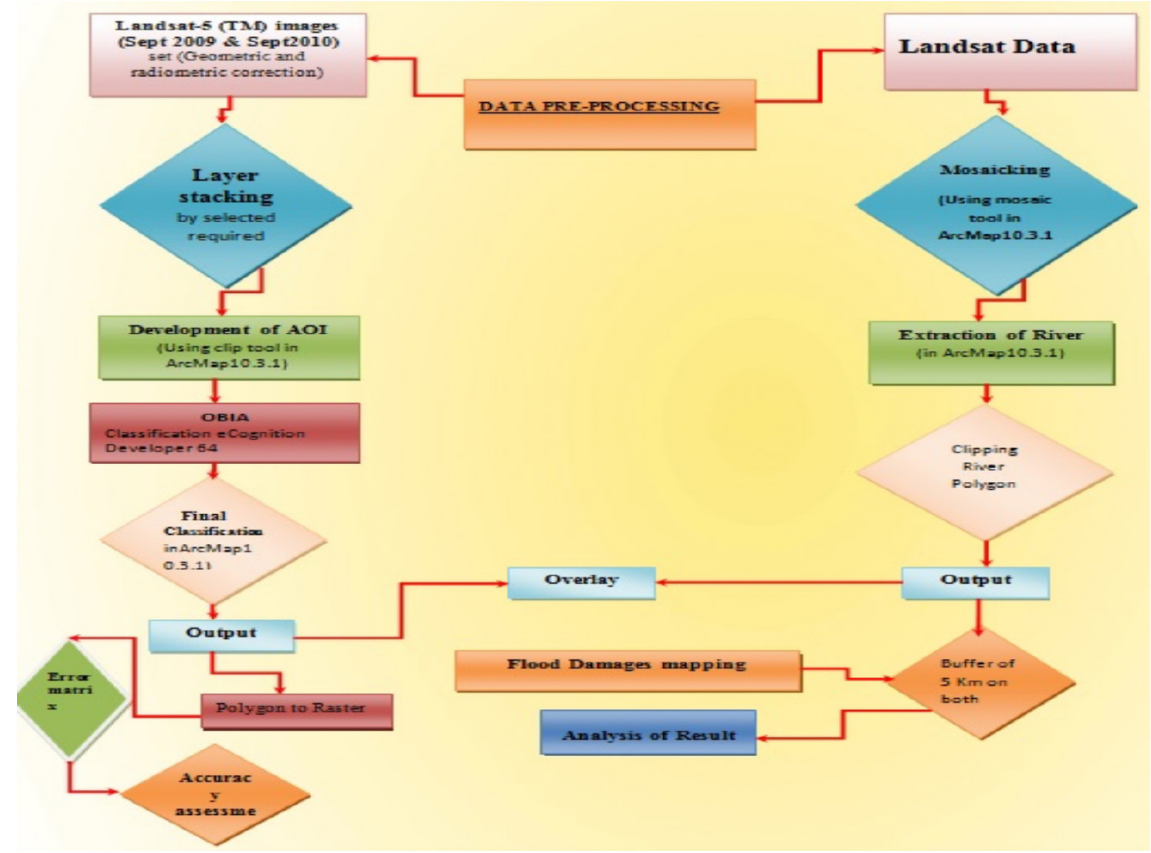

Figure 3. Flowchart shows Data Pre-Processing.

The determination and analysis of flood was carried out by using the two different years image sets, on these sets of image the classification was carried out through Object-Based Image Analysis (OBIA) method, which was performed by using e-Cognition Developer 64(Desktop application), NIR, Green and Red Bands of Landsat -5 (TM) were used to distinguish among Agricultural land, Barren Land (Unused land), Built-up(Roads Settlements etc), vegetation and Water bodies on the different percentage levels of absorption of the spectrum. The river was extracted from Land-sat imageries and overlaid with the land use and land cover (LULC) classification by using map algebra, this layer was used to refine flood damages. Thus the river was overlaid with imagery classifications to obtain final 
desirable results and finally the flooded area was calculated and analyzed with the help of remote sensed data and integration of remote sensing \& GIS tools.

\section{RESULTS AND DISCUSSION}

Floods are common and are costly natural disasters. Generally, floods are local, short-term events which can occur rapidly, sometimes with little or no warning. In this research, a simple and price efficient method was applied to recognize major flood damages along the Indus river basin especially in the upper region of Sindh province including the districts i.e. Kashmore, Ghotki, Sukkur, Shikarpur. Each district has been with the same types of Land use and Land cover (LULG) to recognize the major losses of Crops, Vacant Land, Settlements, vegetation and water bodies as shown in Figure 4.
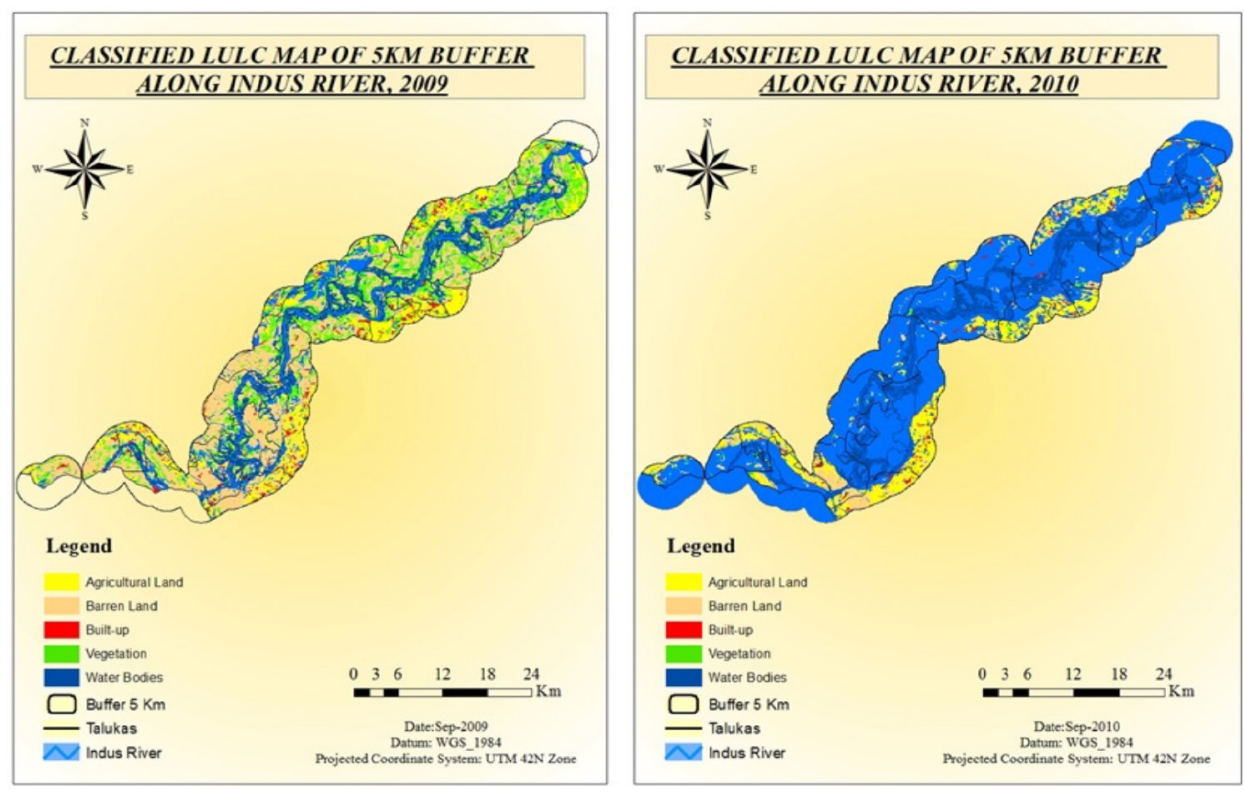

Figure 4. LULC map of the study area.

Landsat-5(TM) imagery of-Sept-2009-Sep 2010 the district Kashmore its three Talukas namely Kashmore, Kandh Kot, and Tangwani having collectively area of $3151.881 \mathrm{~km}^{2}$, while along the river under the $5 \mathrm{~km}$ buffer, area was 1371.615 $\mathrm{km}^{2}$ which classified into (1) Agricultural land(during the summer (Kharif) period 
from June to September mostly area was covered with rice and cotton \& other crops) which was (11.117\%) in 2009 and (8.544\% in Sept 2010) and; (2) Barren Land (including vacant, not suitable for growth of seed, crops, unproductive, and desert land (30.100 \% in 2009 and 4.579\% in 2010); (3) Built-up (including small villages to towns and cities roads) (2.695\% in 2009 and $1.541 \%$ in 2010); (4) Vegetation (35.843\% in 2009 and $0.526 \%$ in 2010); (5) Water Bodies (20.243\%in 2009 and $84.808 \%$ in 2010) these are shown in Table 1 and Figure 5.

Table 1. Different type losses in district Kashmore.

\begin{tabular}{|c|c|c|c|c|c|c|}
\hline Land use & \multicolumn{2}{|c|}{ Image of Sep-2009 } & \multicolumn{2}{|c|}{ Image of 22-Sep-2010 } & \multicolumn{2}{c|}{ Difference } \\
\hline Category & $\begin{array}{c}\text { Area in } \\
\text { Sq Km }\end{array}$ & $\begin{array}{c}\text { Area } \\
\text { \% }\end{array}$ & $\begin{array}{c}\text { Area in } \\
\text { Sq Km }\end{array}$ & $\begin{array}{c}\text { Area } \\
\%\end{array}$ & $\mathbf{k m}^{\mathbf{2}}$ & \\
\hline Agricultural Land & 152.495 & 11.118 & 117.289 & 8.545 & -35.207 & -2.573 \\
\hline Built-up & 36.968 & 2.695 & 21.153 & 1.541 & -15.815 & -1.154 \\
\hline Barren Land & 412.859 & 30.100 & 62.858 & 4.579 & -350.001 & -25.521 \\
\hline Vegetation & 491.633 & 35.843 & 7.225 & 0.526 & -484.408 & -35.317 \\
\hline Water Bodies & 277.660 & 20.243 & 1164.110 & 84.808 & 886.450 & 64.565 \\
\hline Total & 1371.615 & 100.000 & 1372.635 & 100.000 & & \\
\hline
\end{tabular}

\section{District Kashmore}

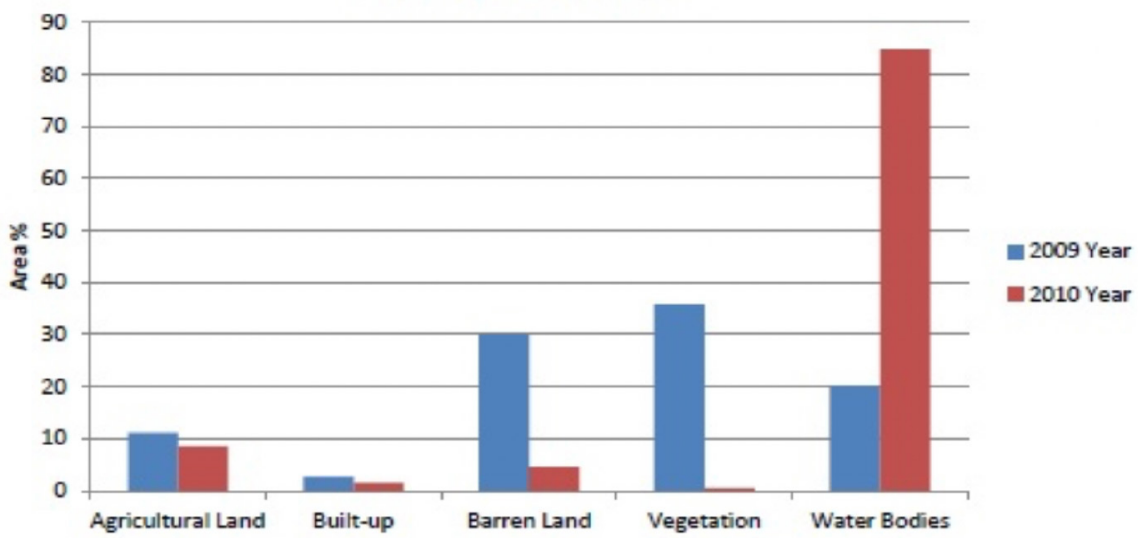

Figure 5. Losses in District Kashmore due to heavy flooding of 2010.

The district Ghotki having an area $5714.004 \mathrm{~km}^{2}$, its only one Taluka namely Ghotki, lies along the river having an area about $112.853 \mathrm{~km}^{2}$ which classified into (1) Agricultural land which was (52.598\%) in 2009; and (45.208\%) in 2010; (2) Barren Land was (14.201\%) in 2009; and (5.304\% in 2010); (3) Built-up $(7.007 \%)$ in 2009; and (1.652\%) in 2010); (4) Vegetation (15.671\%) in 2009; and 
$1.058 \%$ in 2010); (5) Water Bodies (10.5260\% in 2009 and $46.775 \%$ in 2010) are shown in Table 2 and Figure 6.

Table 2. Different type losses in district Ghotki.

\begin{tabular}{|c|c|c|c|c|c|c|}
\hline Land use & \multicolumn{2}{|c|}{ Image of Sep-2009 } & \multicolumn{2}{|c|}{ Image of 22-Sep-2010 } & \multicolumn{2}{|c|}{ Difference } \\
\hline Category & $\begin{array}{c}\text { Area in } \\
\text { Km2 }\end{array}$ & $\begin{array}{c}\text { Area } \\
\text { \% }\end{array}$ & $\begin{array}{c}\text { Area in } \\
\text { Km2 }\end{array}$ & $\begin{array}{c}\text { Area } \\
\text { \% }\end{array}$ & km $^{\mathbf{2}}$ & $\%$ \\
\hline Agricultural Land & 59.359 & 52.598 & 50.826 & 45.209 & -8.533 & -7.390 \\
\hline Built-up & 7.908 & 7.007 & 1.858 & 1.652 & -6.050 & -5.355 \\
\hline Barren Land & 16.028 & 14.203 & 5.964 & 5.305 & -10.064 & -8.898 \\
\hline Vegetation & 17.685 & 15.671 & 1.190 & 1.058 & -16.496 & -14.613 \\
\hline Water Bodies & 11.873 & 10.521 & 52.588 & 46.776 & 40.715 & 36.255 \\
\hline Total & 112.853 & 100.000 & 112.425 & 100.000 & & \\
\hline
\end{tabular}

District Ghotki

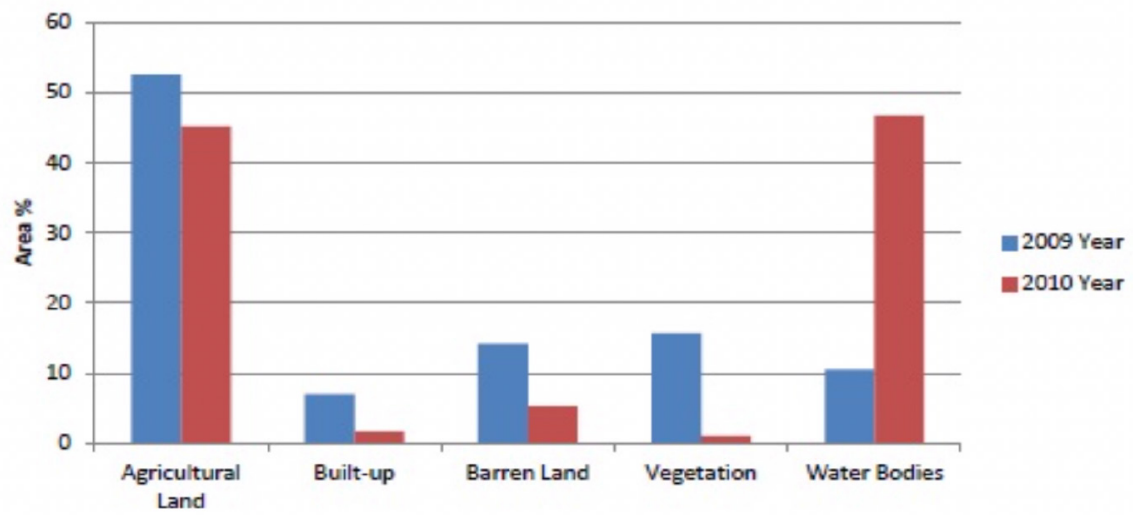

Figure 6. Losses in District Ghotki due to heavy flooding of 2010.

District Sukkur has an area $4720.27 \mathrm{~km}^{2}$, while along the River under the $5 \mathrm{~km}$ buffered area was $707.861 \mathrm{~km}^{2}$ area which classified into (1) Agricultural land was (18.541\%) in 2009 and (21.056\%) in Sept 2010; (2) Barren Land (46.966\%) in 2009 and (66.584\%) in 2010; (3) Built-up (3.885\%) in 2009 and $(2.428 \%)$ in 2010); (4) Vegetation (9.815\%) in 2009 and (0.3788\%) in 2010; (5) Water Bodies $(20.784 \%)$ in 2009 and $(66.739 \%$ in 2010) are shown in Table 3 and Figure 7.

Table 3. Different type losses in Sukkur.

\begin{tabular}{|c|c|c|c|c|c|c|c|}
\hline Land use & \multicolumn{2}{|c|}{ Image of Sep-2009 } & \multicolumn{2}{|c|}{ Image of 22-Sep-2010 } & \multicolumn{2}{|c|}{ Difference } \\
\hline Category & $\begin{array}{c}\text { Area in } \\
\text { Sq Km }\end{array}$ & $\begin{array}{c}\text { Area } \\
\text { \% }\end{array}$ & $\begin{array}{c}\text { Area in } \\
\text { Sq Km }\end{array}$ & $\begin{array}{c}\text { Area } \\
\%\end{array}$ & $\mathbf{k m}^{\mathbf{2}}$ & $\%$ \\
\hline Agricultural Land & 131.295 & 18.548 & 149.214 & 21.057 & 17.919 & 2.509 \\
\hline Built-up & 27.507 & 3.886 & 17.207 & 2.428 & -10.300 & -1.458 \\
\hline Barren Land & 332.455 & 46.966 & 66.590 & 9.397 & -265.865 & -37.569 \\
\hline
\end{tabular}




\begin{tabular}{|c|c|c|c|c|c|c|}
\hline Land use & \multicolumn{2}{|c|}{ Image of Sep-2009 } & \multicolumn{2}{|c|}{ Image of 22-Sep-2010 } & \multicolumn{2}{|c|}{ Difference } \\
\hline Category & $\begin{array}{c}\text { Area in } \\
\text { Sq Km }\end{array}$ & $\begin{array}{c}\text { Area } \\
\%\end{array}$ & $\begin{array}{c}\text { Area in } \\
\text { Sq Km }\end{array}$ & $\begin{array}{c}\text { Area } \\
\%\end{array}$ & $\mathbf{k m}^{\mathbf{2}}$ & $\%$ \\
\hline Vegetation & 69.478 & 9.815 & 2.685 & 0.379 & -66.793 & -9.436 \\
\hline Water Bodies & 147.127 & 20.785 & 472.933 & 66.739 & 325.807 & 45.955 \\
\hline Total & 707.862 & 100.000 & 708.629 & 100.000 & & \\
\hline
\end{tabular}

\section{District Sukkur}

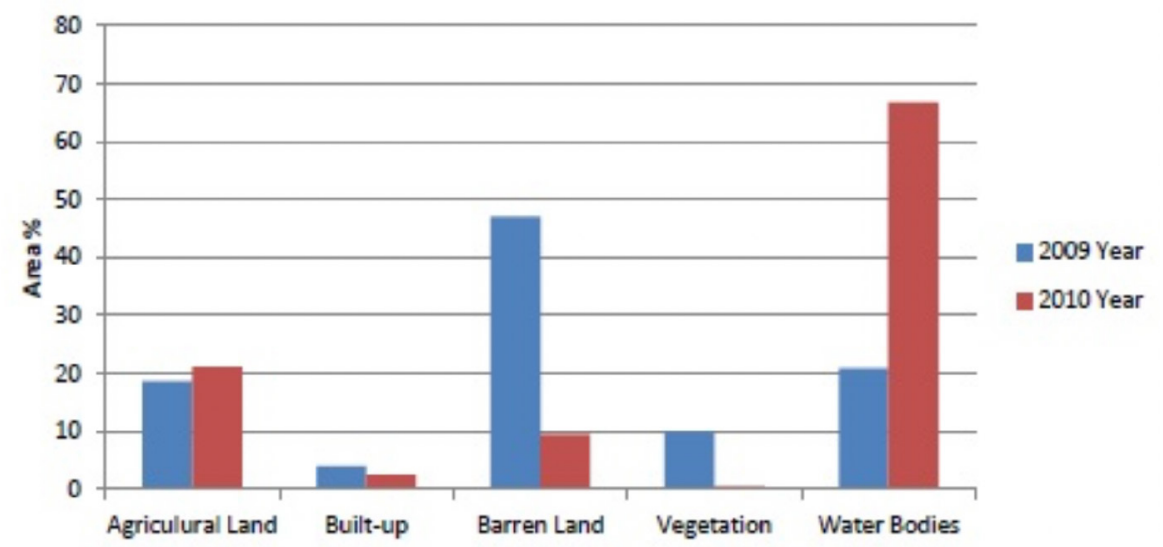

Figure 7. Losses in District Sukkur due to heavy flooding of 2010.

District Shikarpur and its three Talukas such as Garhi Yasin, Khan Pur, Khan Pur, have collectively area $806.846 \mathrm{~km}^{2}$ while along the River under the $5 \mathrm{~km}$ buffered area was $566.911 \mathrm{~km}^{2}$ which classified into (1) Agricultural land which was (10.392\%) in 2009 and (8.592\%) in Sept 2010); (2) Barren Land (53.013\%) in 2009 and (6.120\%) in 2010; (3) Built-up (2.337\%) in 2009; and (0.970\%) in 2010; (4) Vegetation (18.879\%) in 2009 and (1.606\%) in 2010; (5) Water Bodies (15.377\%) in 2009 and $(66.739 \%)$ in 2010) which is shown in Table 4 and Figure 8.

Table 4. Different type losses in district Shikarpur.

\begin{tabular}{|c|c|c|c|c|c|c|}
\hline Land use & \multicolumn{2}{|c|}{ Image of Sep-2009 } & \multicolumn{2}{|c|}{ Image of 22-Sep-2010 } & \multicolumn{2}{|c|}{ Difference } \\
\hline Category & $\begin{array}{c}\text { Area in } \\
\text { Sq Km }\end{array}$ & $\begin{array}{c}\text { Area } \\
\text { \% }\end{array}$ & $\begin{array}{c}\text { Area in } \\
\text { Sq Km }\end{array}$ & $\begin{array}{c}\text { Area } \\
\%\end{array}$ & $\mathbf{k m}^{\mathbf{2}}$ & $\%$ \\
\hline Agricultural Land & 58.919 & 10.393 & 49.119 & 8.593 & -9.799 & -1.800 \\
\hline Built-up & 13.249 & 2.337 & 5.582 & 0.976 & -7.667 & -1.361 \\
\hline Barren Land & 300.538 & 53.013 & 34.986 & 6.120 & -265.552 & -46.893 \\
\hline Vegetation & 107.031 & 18.880 & 9.186 & 1.607 & -97.845 & -17.273 \\
\hline Water Bodies & 87.174 & 15.377 & 472.759 & 82.703 & 385.585 & 67.326 \\
\hline Total & 566.911 & 100.000 & 571.633 & 100.000 & & \\
\hline
\end{tabular}




\section{District Shikarpur}

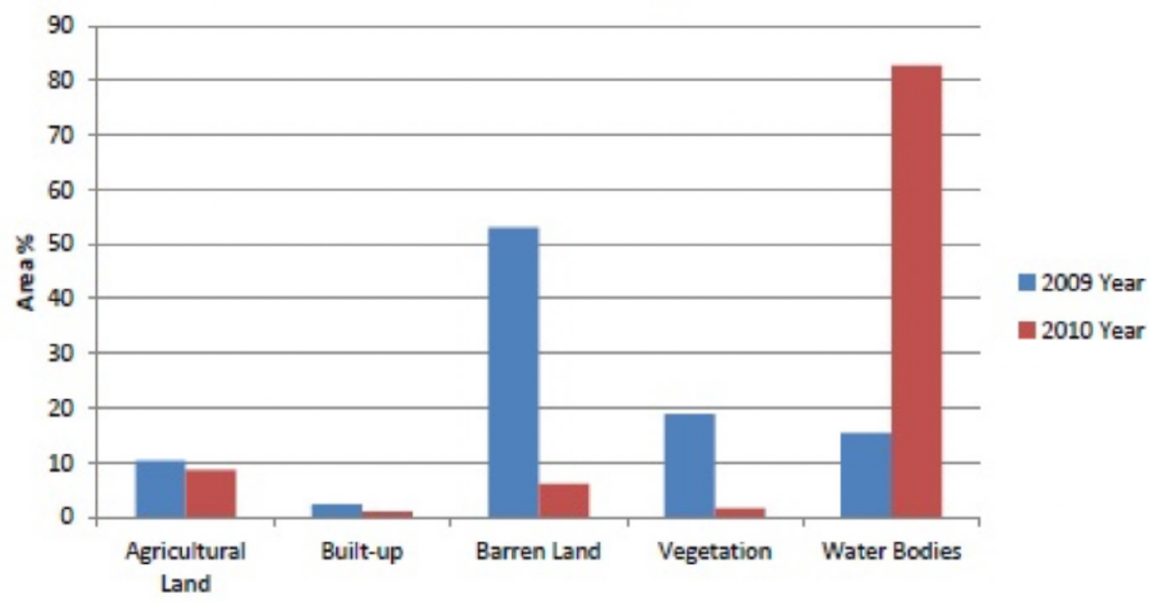

Figure 8. Losses in District Shikarpur due to heavy flooding of 2010.

The LULG classification explained loss of Agricultural land Barren Land, Builtup, Vegetation caused by flooding of 2010, also the flood map of the study region which is shown in Figure 4, indicated that around the $5 \mathrm{~km}$ on both sides the area which is under Indus basin is destroyed including Kashmore, its three talukas namely Kashmore, Kandhkot and Tagwani, District Ghotki its Ghotki Taluka, District Sukkur its three Talukas such as Rohri, Sukkur and Pano Akil District Shikarpur its three Talukas such as Garhi Yasin, lakhi and Khan Pur.

\section{ACCURACY ASSESSMENT}

For the accuracy assessment, the Kappa coefficient and overall accuracy techniques have been applied to verify the land use classification. While an analytical technique i.e. the error matrix was also used and calculated, then producer's accuracy was determined, it is the possibility in which a pixel in the recognized image is positioned in the similar class on the ground. Meanwhile, the true pixel in every class is divided by the sum of the pixel class which is obtained from the reference data. The possibility of reference pixels which are properly classified is called a producer's accuracy. Whereas the accuracy in which overall 
true pixels of the ground is divided by the sun of pixels which classified in a class is called as user's accuracy, it is an analytical possibility in which the pixels are classified on the image that actually shows the category on the ground. However, the user's accuracy is the possibility of a specific class of ground which is classified in similar class on the classified image as shown in Table 5 and 6.

Table 5. Error matrix used to assess the accuracy of a classification of the Sept 2009 Landsat TM image.

\begin{tabular}{|c|c|c|c|c|c|c|c|}
\hline & \multicolumn{7}{c|}{ Reference Data Landsat 5 Sep-2009 } \\
\hline Data & Agricultural & Classified & Water \\
\hline Land & Built-up & Barren Land & Vegetation & $\begin{array}{c}\text { Wotal } \\
\text { Bodies }\end{array}$ & $\begin{array}{c}\text { User } \\
\text { Accuracy \% }\end{array}$ \\
\hline Agricultural Land & 256 & 0 & 0 & 10 & 0 & 266 & 96.24 \\
\hline Built-up & 0 & 129 & 0 & 0 & 0 & 129 & 100 \\
\hline Barren Land & 0 & 8 & 32 & 4 & 0 & 40 & 80 \\
\hline Vegetation & 2 & 0 & 0 & 1098 & 4 & 1100 & 99.81 \\
\hline Water Bodies & 1 & 0 & 0 & 21 & 454 & 476 & 95.45 \\
\hline $\begin{array}{c}\text { Total } \\
\text { Producer }\end{array}$ & 259 & 137 & 32 & 1133 & 1133 & & \\
\hline Accuracy \% & 98.84 & 94.16 & 100 & 96.91 & 98.84 & & \\
\hline
\end{tabular}

Table 6. Error matrix used to assess the accuracy of a classification of the Sept 2010 Landsat_8 image.

\begin{tabular}{|c|c|c|c|c|c|c|c|}
\hline & \multicolumn{7}{c|}{ Reference Data Land-sat 5 TM 2010 } \\
\hline Data & Agricultural & \multicolumn{7}{c|}{ Classified } \\
\hline Land & Built-up & Barren Land & Vegetation & $\begin{array}{c}\text { Water } \\
\text { Bodies }\end{array}$ & Total & $\begin{array}{c}\text { User } \\
\text { Accuracy \% }\end{array}$ \\
\hline Agricultural Land & 1104 & 0 & 0 & 82 & 0 & 1186 & 96.24 \\
\hline Built-up & 0 & 342 & 0 & 3 & 0 & 3 & 96.24 \\
\hline Barren Land & 0 & 6 & 65 & 0 & 0 & 0 & 96.24 \\
\hline Vegetation & 3 & 0 & 1 & 11610 & 0 & 11613 & 96.24 \\
\hline Water Bodies & 0 & 0 & 0 & 17 & 66 & 83 & 96.24 \\
\hline Total & 1107 & 348 & 66 & 11712 & 66 & & \\
\hline $\begin{array}{c}\text { Producer } \\
\text { Accuracy \% }\end{array}$ & 98.84 & 98.84 & 98.84 & 98.84 & 98.84 & \\
\hline
\end{tabular}

\section{CONCLUSION}

The availability of remote sensing data and GIS techniques helped to recognize the major flood impacts before and after the flooding of 2010 along the Indus river basin. However the flood damages such as Infrastructural, loss of Agriculture, Built-up (Houses), natural vegetation and property have been identified and also its extent has been measured by using Landsat imageries i.e. September 2009 and September 2010, and the results have been achieved through integration of Remote Sensing (RS) and Geographical Information System (GIS) techniques. 


\section{REFERENCES}

Anderegg, W. R. L., Prall, J. W., Harold, J. \& Schneider, S. H. (2010). Expert credibility in climate change. Proceedings of the National Academy of Sciences of the United States of America, 107(27), pp. 12107-12109. doi: http://dx.doi. org/10.1073/pnas. 1003187107

BBC. (2010). Pakistan floods cause 'huge losses' to crops. (http://www.bbc. co.uk/news/world-south-asia-10948275). Archived https://web.archive. org/web/20100812033329/http://www.bbc.co.uk/news/world-south-asia10948275) from the original on 12 August 2010. Retrieved 12 August 2010.

Dang, N., Babel, M. \& Luong, H. (2011). Evaluation of food risk parameters in the Day River Flood Diversion Area, Red River Delta, Vietnam. Natural Hazards, 56(1), pp. 169-194. doi: http://dx.doi.org/10.1007/s11069-0109558- $\mathrm{x}$

Duttaa, D., Herathb, S. \& Musiake, K. (2003). A mathematical model for flood loss estimation. Fournal of Hydrology, 277(1-2), pp. 24-49. doi: http:// dx.doi.org/10.1016/S0022-1694(03)00084-2

Hapuarachchi, H. A. P., Wang, Q. J. \& Pagano, T. C. (2011). A review of advances in flash flood forecasting. Hydrological Processes, 25(18), pp. 2771-2784. doi: http://dx.doi.org/10.1002/hyp. 8040

Haq, M., Memon, A., Muhammad, S., Sidiqui, P. \& Rahmatullah, J. (2012). Techniques of Remote Sensing and GIS for flood monitoring and damage assessment: A case study of Sindh province, Pakistan. The Egyptian Journal of Remote Sensing and Space Science, 15(2), pp. 135-141. doi: http://dx.doi. org/10.1016/j.ejrs.2012.07.002

Irimescu, A., Graciunescu, V., Stancalie, G. \& Nertan, A. (2010). Remote sensing and GIS techniques for flood monitoring and damage assessment. Study Case in Romania. BALWOIS. In Jones, J. A., Vardanian, T \& Hakopian, C. Threats to Global Water Security (pp. 167-177). doi: http:// dx.doi.org/10.1007/978-90-481-2344-5 
PDMA. Sindh. (2011). Sindh Provincial Monsoon/Floods contingency plan 2011. Government of Sindh Rehabilitation Department Provincial disaster Management Authority Retrieved from https:/ / www.google.com.pk/search?q=2FFloods+contingency+ plan+2011+Draft+versions 1.0+Government+of+Sindh+Rehabilitation+Department+Provincial + disaster + management + Authority.\&rlz=1C1GGRV_enPK 751PK 751\&oq=Sindh+Provincial+Monsoon \%2FFloods+contingency+plan+2011+Draft+versions 1.0+Government+of+Sindh + Rehabilitation + Department + Provincial+disaster + management $+\mathrm{Au}-$ thority.\&aqs $=$ chrome. .69i57.3501j0j4\&sourceid $=$ chrome\&ie $=U T F-8$.

Sellers, W. D. (1969). A global climatic model based on the energy balance of the earth-atmosphere system. Journal of Applied Meteorology, 8(3), pp. 392-400. doi: http://dx.doi.org/10.1175/1520-0450(1969)008<0392:A$\mathrm{GGMBO}>2.0 . \mathrm{CO} ; 2$

Trianni, G. \& Gamba, P. (2008). Damage Detection from SAR Imagery: Application to the 2003 Algeria and 2007 Peru Earthquakes. International Fournal of Navigation and Observation, 2008, 8. doi: http://dx.doi. org/10.1155/2008/762378 


\section{AUTHORS}

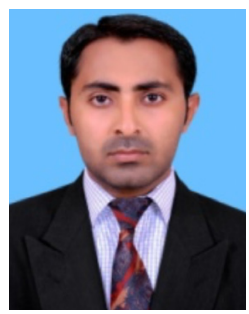

\section{Sikandar Ali}

He received his MS degree in Remote Sensing and GIS from Karachi University Pakistan, Currently working as lecturer at Faculty of Engineering, Science \& Technology, Indus University Karachi, Pakistan.

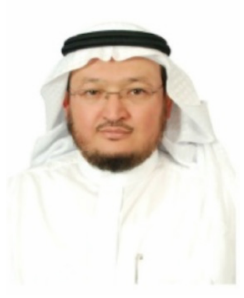

\section{Dr. Gasim Alandjani}

Dr. Gasim Alandjani received his PhD Computer Engineering degree from New Mexico State University (USA), He has 28 years' experience of teaching and research including management experience as Dean, Makkah College of Technology-2003-2009, Deputy Managing Director of Yanbu Industrial College 2010-2012, managing Director of Yanbu Industrial College 2012-2013. Currently, he is working as senior faculty Member in Computer science and Engineering Department (CSE) at Yanbu University College Royal Commission Yanbu, Kingdom of Saudio Arabia. 
Edición Especial Special Issue Mayo 2019

DOI: http://dx.doi.org/10.17993/3ctecno.2019.specialissue2.258-275 